\title{
Socio-economic analysis of Baroda branch canal of Som Kamla Amba irrigation project, Dungarpur, Rajasthan
}

\author{
Kishan Makadiya \\ Soil and Water Engineering Department of CTAE, MPUAT, Udaipur, Rajasthan, India \\ R C Purohit \\ Soil and Water Engineering Department of CTAE, MPUAT, Udaipur, Rajasthan, India \\ Jitendra Rajput 的 \\ Division of Agricultural Engineering, IARI, New Delhi, India \\ Dimple \\ Soil and Water Engineering Department of CTAE, MPUAT, Udaipur, Rajasthan, India \\ Ashish Rai \\ KVK Parsauni, RPCAU, Pusa, Bihar, India \\ Ahmed Elbeltagi \\ Agricultural Engineering Dept, Faculty of Agriculture, Mansoura University, Mansoura, Egypt \\ College of Environmental and Resource Sciences, Zhejiang University, Hangzhou, China
}

\begin{tabular}{|c|c|}
\hline ARTICLE INFO & ABSTRACT \\
\hline $\begin{array}{l}\text { Received : } 22 \text { May } 2021 \\
\text { Revised : 05 July } 2021 \\
\text { Accepted : } 25 \text { July } 2021 \\
\text { Available online: } 19 \text { December } 2021 \\
\text { Key Words: } \\
\text { Baroda Branch Canal } \\
\text { Command area } \\
\text { Socio-economic analysis } \\
\text { Irrigation } \\
\text { Irrigation efficiency } \\
\text { Som Kamla Amba IrrigationProject }\end{array}$ & $\begin{array}{l}\text { Irrigation system development results in improvements of farmers' economic } \\
\text { condition, followed by livelihood sustainability, standard of living and social } \\
\text { attitude. Present analysis focused on socio-economic status of farming families } \\
\text { in the command area of Baroda Branch Canal of Som Kamla Amba Irrigation } \\
\text { Project. The study considered survey sampling of } 10 \text { per cent beneficiaries in } \\
\text { the Baroda branch canal command which consisted } 150 \text { farming families } \\
\text { having } 787 \text { persons in numbers. The socio-economic indicators viz., the family } \\
\text { structures, employment pattern, education status, livestock ownership, farm } \\
\text { asset distribution, cost of cultivation, and cost of returns were } \\
\text { analysed. Results indicated that education and living standards are of farmers } \\
\text { was low which may be one of the reasons for not adoption of newly farming } \\
\text { technologies. Cost of cultivation per hectare for wheat, barley, gram, and } \\
\text { mustard crops were found as Rs. } 28,503.00 \text {, Rs. } 26,727.00 \text {, Rs. } 21,184.00 \text { and } \\
\text { Rs. } 21,697.00, \text { respectively and net benefits per hectare obtained from these } \\
\text { crops were Rs. } 13,297 \text {, Rs. } 13,023, \text { Rs. } 14,416 \text { and Rs. } 18,303 \text {, respectively. The } \\
\text { pattern of ownership of livestock showed that the average number of cows in } \\
\text { the command area was about } 1.97 \text { per family. The productivity in the area is } \\
\text { average due to low inputs use. }\end{array}$ \\
\hline
\end{tabular}

\section{Introduction}

Poor irrigation performance, mainly in many irrigation schemes globally, results in important social, economic and environmental problems, so that the modernization of these areas is required to ensure their profitability and sustainability. Performance analysis of irrigation schemes is essential to improve the systems performance (Rajput et al., 2017a). Irrigation schemes are evaluated using technical, maintenance and comparative performance indicators (Rajput et al., 2017b; 2017c; Molden et al., 2007). Socio- economic study helps in evaluating the impacts occurred to implementation of irrigation project. Borkar et al. (2000) reported that the highly significant association was seen between educations of the farmers with their knowledge level of biofertilizers. Age, land holding, annual income, socio economic status, extension contact and civilitycharacteristics of the farmers were found. Jain (2000) carried out socio-economic survey of 50 farmers in command of Nimoda minor concluded that in the command 55 percent of the

Corresponding author E-mail: jitu.caepht@gmail.com

Doi: https://doi.org/10.36953/ECJ.2021.22332

This work is licensed under Attribution-Non Commercial 4.0 International (CC BY-NC 4.0)

(C) ASEA 
total farmers were under small land holding. Socioeconomic study revealed that per capita per annum income from agricultural activities was Rs. 5496.00. Machiwal (2001) conducted the study of socio-economic status of 45 sampled farmers on the head, middle and tail reaches of Right Main Canal of Jakham irrigation project and concluded that the agriculture is the main occupation of the farmers who were the mostly tribal, their literacy percentage and family assets were very low and therefore, the farmers were not aware of new technologies of farming. Chahar and Chaudhri (2003) conducted the socio-economic survey in Suratgarh area of Indira Gandhi Nahar Pariyojana. The survey revealed that the income of the farmers has increased after commencement of the canal, it is reached to a maximum and then started to decline due to water logging. They concluded that 10 percent farmers have land holding of less than 10 bigha, 35 percent between 10-20 bigha, 45 percent between 20-30 bigha and 10 percent above 30 bigha, implying that medium size holdings predominate in the surveyed area. Further, 42.5 percent farmers have their area partially affected by water logging while 57.5 percent land holdings were wholly water logged among the surveyed farmers. The study was conducted among the selected farmers, who were taking wheat crop in Sriganganagar district of Rajasthan. Arya (2005) studied LMC command of Som-Kagdar irrigation project. Almost all the farmers in the command area were hiring machines for field preparation and cultivation practices which show the low economic level of the farmers in the command, cost of cultivation of wheat, gram and barley were Rs. 14736.70, Rs. 9036.50 and Rs. 8723.80 per hectare respectively and net benefits obtained from these crops were Rs. 6432.90, Rs. 5214.70 and Rs. 8131.20 per hectare.

Small land holders in irrigation schemes appear relatively wealthy compared to marginalized peasants without access to irrigable land. Sufficient area of irrigable land seems crucial to provide sufficient income; an optimal land allocation of the scarce areas appears necessary (Hagel et al., 2019). Singh et al., (2012) study reveals that whereas $87 \%$ farmers in the head reach and $65 \%$ of farmer in the middle reach, it is only $10 \%$ farmers in the tail reach are satisfied with present situation of canal command. Percentage of farmer contributing towards the maintenance of the irrigation system are found to be $47.5 \%, 25 \%$ and $7.5 \%$ in head, middle and tail reach, respectively. Varhade et al., (2013) worked on "Realistic study of Rehabilitation and Resettlement of Project Affected Persons (PAP's) of Gosikhud Project in Maharashtra State". They found that area of RV (Rehabilitated Villages) is 4 times that of AV (Affected Villages); while population density at RV is found out to be 39 persons/ha as compared to 175 persons/ha in case of AV. This clearly shows that PAP's are being provided more space for their new habitat. They also concluded that $48.42 \%$ of PAP's are landless or marginal farmers, it means that $51.16 \%$ of households possess farms of more than 1 ha. Akkuzu et al., (2007) indicated that diagnostic analysis of entire canal network is essential to identify the operational problems as well as for socio-economic status survey of the peoples living within the command. Community tubewell schemes improves the income and thereby livelihood of farmers (Singh et al.,2020; Ananta Raj Dahal, 2013). Therefore, socio-economic evaluation is needed to implement any new technology or scheme in the command area to improve existing level of technology adoption for achieve higher production. This investigation conducted to evaluate the impact of irrigation project on socioeconomic status of farmers in the command area of Baroda branch canal of Som Kamla Amba irrigation project.

\section{Material and Methods Description of study area}

Som Kamla Ambba irrigation project is a major project in the Dungarpur district, Rajasthan, India. The gross command area (GCA) of the project is 25088 ha with culturable command area (CCA) of 17724 ha. The live storage capacity of reservoir is $160.3 \mathrm{M}$ cum. Dead storage capacity is $12.5 \mathrm{M}$ cum. The command area of Som Kamla Amba project lies on both banks of Som River. The total numbers of villages benefited are 57 . The location map of study area and line diagram of Baroda branch canal of Som Kamla Amba irrigation project are shown in (figure 1) and (figure 2), respectively. 


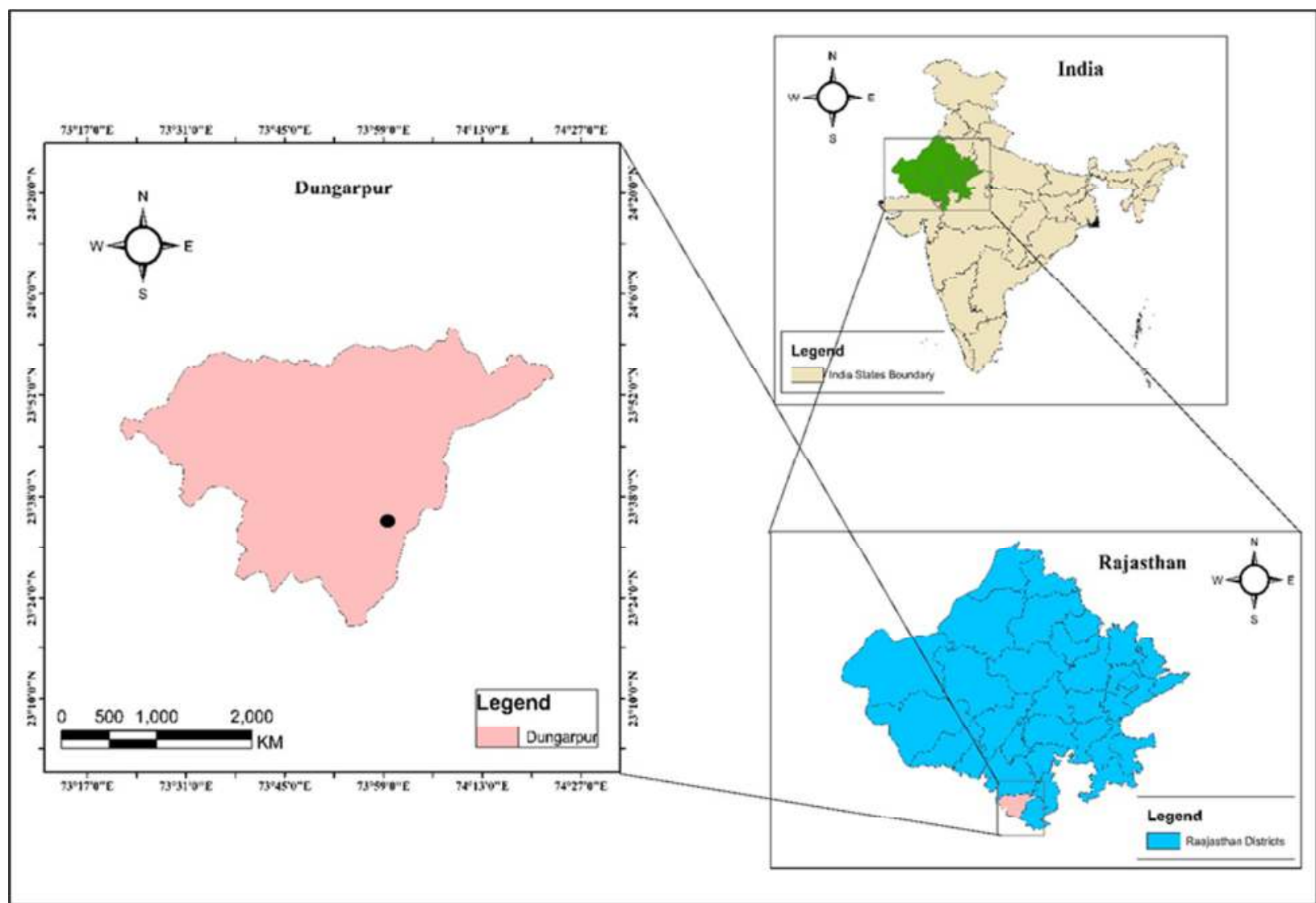

Figure 1: Location map of Som Kamla Amba irrigation project

\section{Socio Economic Status of Farmer's}

The technical and socio-economic constraints that prevent farmers from achieving the output potential of their farms differ among countries and even amongst region within a country. The role of socioeconomic study is to delineate economic and social problems and to identify the losses associated with technical, institutional, social and economic constraints. It is also imperative that if we are going to implement some planned technology in a region then we should be familiar with the social and economic conditions of that region to get success in the implementation. The present study deals with determination of socio-economic status of the farmers in the command area of Baroda Branch Canal (BBC) of Som Kamla Amba irrigation project with reference to age, level of education, social participation, land holding, farm $\&$ non-farm assets. The different techniques used for measuring the socio- economic status and procedure for collection of samples and the data are given below. a. Selection of Farmers

A complete list of all head, middle and tail end cultivators of the minors on the $\mathrm{BBC}$ was obtained. A sample of 10 percent of total farmers of command area of the BBC was chosen for the study. Equal representation has been given to head, middle and tail end of each minor while selecting the sample at randomly. Likewise, 150 farming families were selected in the study command area. As there is undulating and very less land holding in the command, it is difficult to classify them as small, medium and large farm size.

\section{b. Collection of Data}

To fulfil the objectives of the study, both primary and secondary data were collected. The required information was collected personally by contacting the main system officials the other lower division official, irrigation staff (Irrigation Patwari etc.) and farmers in the selected minors. All the data and information collected for the study can be divided into two groups viz., macro and micro level. 


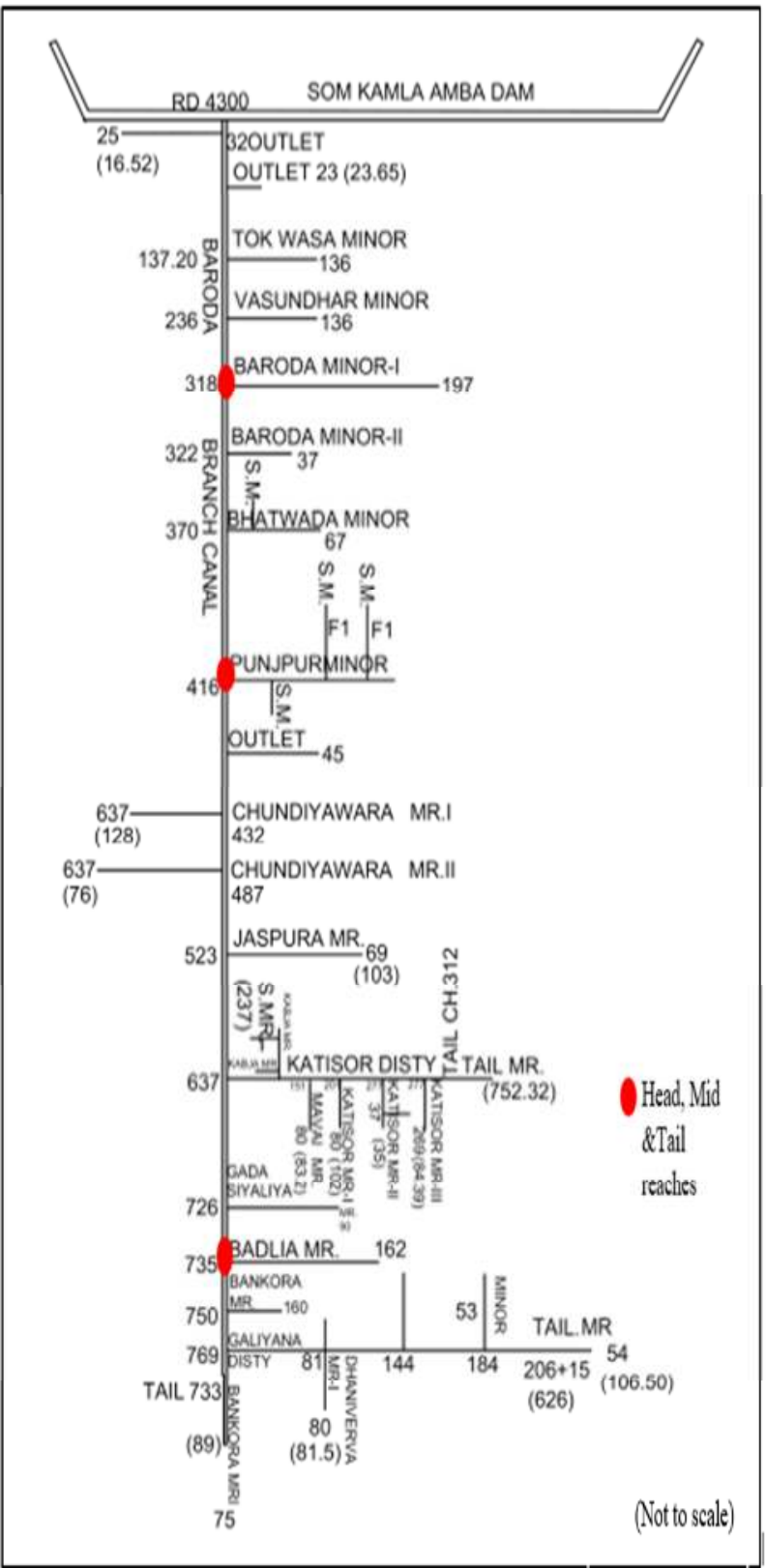

Figure 2: Line diagram of BBC of Som Kamla Amba irrigation project.

\section{Results and Discussion}

Development of agriculture in area brings about changes in the economy of farmers, followed by changes in economic and social attitude of the people. These changes are reflected in level of education, pattern of agricultural production and the occupational distribution etc. In the area with the commencement of irrigation, there have been slight changes in socio-economic status of the farmers of this particular command area though the process of transformation has been comparatively slow. Due to illiteracy and lack of knowledge the farmers were slow to adopt the appropriate procedure regarding crop production and other agronomic practices recommended by the concerned departments. This section deals with the socioeconomic status of the sample farmers in the command area. Family composition, occupational pattern, ownership of livestock, farm assets distribution, cost of cultivation and cost of returns are the major components of the analysis. In the command area, there were 150 families surveyed, which is approximate 10 percent of total cultivator. The survey covered 787 persons.

\section{a. Family Composition of the Sample Farmers}

The information of each family member was collected through survey questionnaire such as number of family members, migration, age, sex, education level and occupation of family members etc. Average family size in the command area is 5 members per family. (Figure 3 ) shows number of family members and percentage of facilities.

\section{b. Details of different age group}

(Figure 4) shows the age group wise population. Highest population falls in the age group of 11-20 followed by 21-30 age group with population percentage of 22.36 and $19.95 \%$, respectively. Lowest population was in the age group of 71-90.

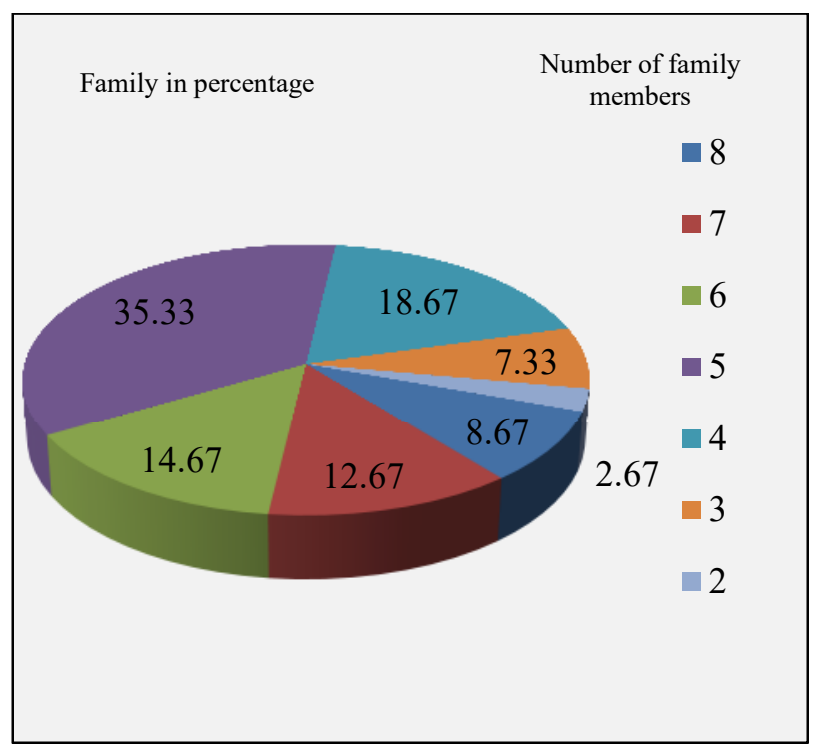

Figure 3: Number of family members and family percentage 


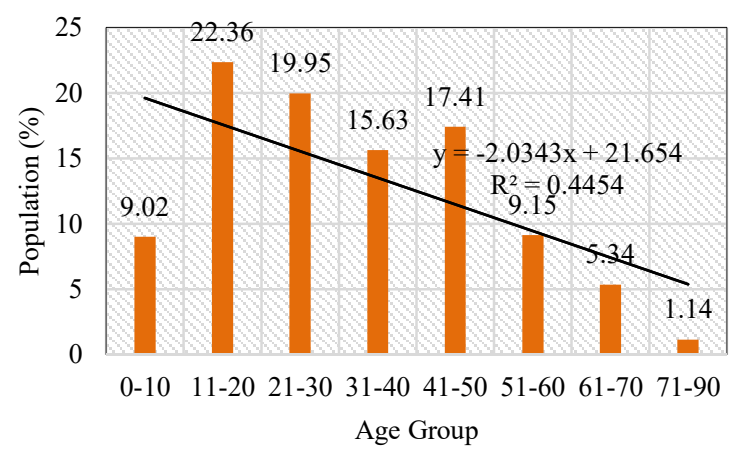

Figure 4: Different age group in the command area.

\section{c. Details of male and female surveyed in command area}

Female population in the command area is more than male population. (Table 1) shows the population of male and female.

\section{d. Education level of surveyed population in command area}

Education level of surveyed area sample is given in (figure 5). It is clear from the table that $84.37 \%$ population is literate.

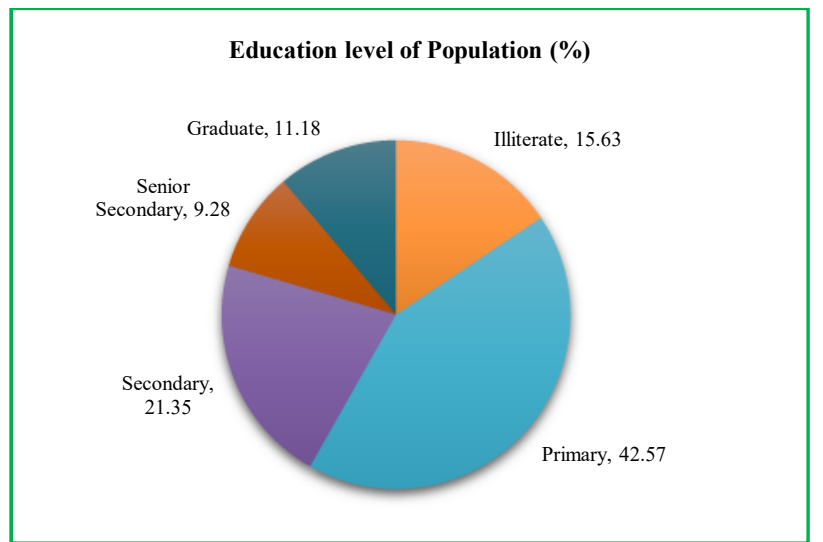

Figure 5: Education level of sample population in command area

\section{e. Buildings}

As per survey only 8 families lived in Pakka house, 29 families lived in Partial Pakka house and rest were lived in Kachcha house before irrigation project, whereas at present 31 families lives in Pakka house, 70 families lives in Partial Pakka house and 49 families lives in Kachcha house after irrigation project. The present status of residential building of surveyed family is shown in (figure 6).

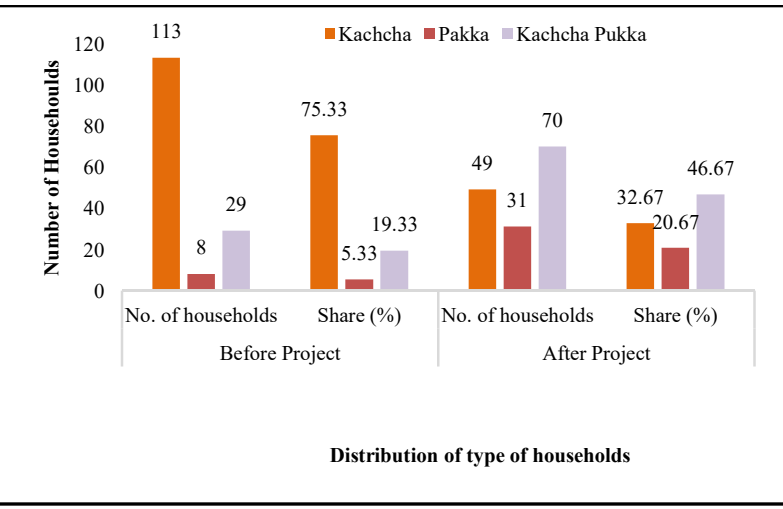

Figure 6: Residential building of sample family

\section{f. Migration Details}

There were seasonal and long duration migration was found 16.01 percent for employment. Most of people are going for labour work employment in nearby towns, tehsil headquarters, districts headquarters and states.

\section{g. Land Value}

Before irrigation project, average value of irrigated land was Rs. 31000 per bigha and unirrigated land was Rs. 23000 per bigha, because in that time span, the most of area was unirrigated and therefore, low crop production due unavailability of assured irrigation source. After irrigation project, there are drastically changes in land value due to increase in irrigation facility and production, because of almost all area is irrigated through canal networks and suitable for all type of crops. At present, the value of irrigated land is approximate Rs. 79000 per bigha and unirrigated land Rs. 60000 per bigha. There has been seen $60.79 \%$ increase in the irrigated land value and $61.66 \%$ increase in unirrigated land value.

\section{h. Age and Social Participation of the Farmers}

The analysis states that most of the farmers belonged to young age group i.e. (below 30 years) which was followed by middle age group (i.e., 31 to 49 years) and old (above 50 years) farmers. In the age group of young, middle and old farmers there were 51.33, 33.04 and $15.63 \%$ farmers, respectively. Farmers involved in any social organization as Panchayat were considered under social participation. Only 7.12 percent farmers were found in active participation in social organization 
in the study area. It means that most of the farmers have no interest in social activities.

\section{i. Distribution of Farm Assets of Sample Farmers}

The distribution of farm assets shown in figure 7. Almost all the farmers in the command area were hiring machines for field preparation and cultivation practices. The economic level of the farmers in the command is low. Some farmers in the command area were without lands and they work as a farm labour on the other farmer's land. It is observed that major portion of farm assets is devoted to Khurpi, Spade, Gaiti, Indigenous plough, sprayer, Diesel engine and Kudali contributing 21.21, 20.51, 13.68, 8.39, 6.92, 5.05 and $4.51 \%$, respectively.

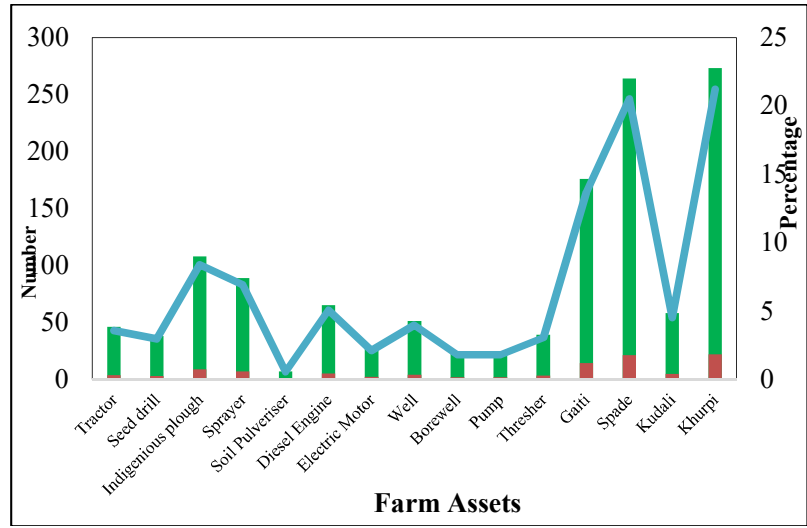

Figure 7: Distribution of farm assets of sample farmers

Table 1: Details of male and female surveyed in command area

\begin{tabular}{|c|c|c|c|}
\hline SN & Sex & No.of persons & Population (\%) \\
\hline 1 & Male & 379 & 48.16 \\
\hline 2 & Female & 408 & 51.84 \\
\hline
\end{tabular}

Table2: Ownershipof livestocks ofthesamplefarmers

\begin{tabular}{|c|c|c|c|c|}
\hline SN & Particulars & Number & No./Family & Percentage \\
\hline 1 & Cow & 295 & 1.97 & 56.30 \\
\hline 2 & Buffallo & 229 & 1.53 & 43.70 \\
\hline
\end{tabular}

\section{j. Distribution of Non-Farm Assets of the Sample Farmers}

On the analysis of obtained data from selected farmers in command area, number of non-farm assets per family and their percentage individually shown in figure 8. It is observed from figure that major portion of non-farm assets is devoted to Chairs, Fan, Cycle, Almirah, and Radio contributing 22.84, 15.79, 8.44, 8.33, and 8.10 percent, respectively, of total non-farm assets. Most of the farmers do not have any non-farm assets in the command area. It means almost all the farmers come under very low economic condition.

\section{k. Ownership of Live Stocks of the Sample Farmers}

The pattern of ownership of livestock in the selected farmers is presented in Table 2. The average number of cows in the command area was found 1.97 per family. The average buffaloes were estimated 1.53 per family in the command area.

\section{Occupational Pattern of the Sample Farmers}

Figure 9 clearly depicts that most of the farmers practice farming as a major source of living in their own farm. Most of the adult women performed farming practices along with domestic work. Only 5.34 percent of total family members were on service in government and private organizations in nearly cities or villages.

\section{m. Cropping Pattern of the Project Area}

Cropping patterns in a location are ascertained by a diverse array of factors, including climate, land quality, domestic water need, moisture levels, relative profitability, farmer managerial skills, and a number of other factors. Proper monitoring of cropping pattern in the project area is inevitable. Field data regarding the existing cropping pattern were collected from Aspur Tehsil office. The most dominating crop is Maize in Kharif season, while in Rabi season, Wheat is the dominant crop. From figure 10, it becomes clear that the dominant crop wheat covers about 72 percent and remain crops (Gram, mustard, and barley etc. in Rabi season) are' grown in only 27 percent of total cropped area.

\section{n. Cost of Cultivation and Net Benefit of Rabi Crops in Command Area}

There are varying charges for irrigation of different crops and crop wise irrigation charges for different crops. Table 3 shows the prevailing irrigation rate. Using these irrigation charges, the cost of cultivation of wheat, barley, gram, and mustard, were Rs. 28,503.00, Rs. 26,727.00, Rs. $21,184.00$ and Rs. 21,697.00 per hectare, respectively and net benefits obtained from these crops were Rs. 13,297, Rs. 13,023 , Rs. 14,416 and Rs. 18,303 per hectare. Crop cultivation of wheat crop is shown in table 4 . 
Table 3: Crop wise irrigation charges

\begin{tabular}{|c|c|c|c|}
\hline SN & Crop & Rates in Rs/acre & Rates in Rs/ha \\
\hline 1 & Wheat & 60 & 150 \\
\hline 2 & Mustard & 46 & 115 \\
\hline 3 & Gram & 44 & 110 \\
\hline 4 & Coriander & 52 & 130 \\
\hline 5 & Barley & 33 & 80 \\
\hline 6 & Vegetables & 44 & 110 \\
\hline 7 & Lucern & 44 & 110 \\
\hline 8 & Garlic & 52 & 130 \\
\hline 9 & Other crops & 44 & 110 \\
\hline
\end{tabular}

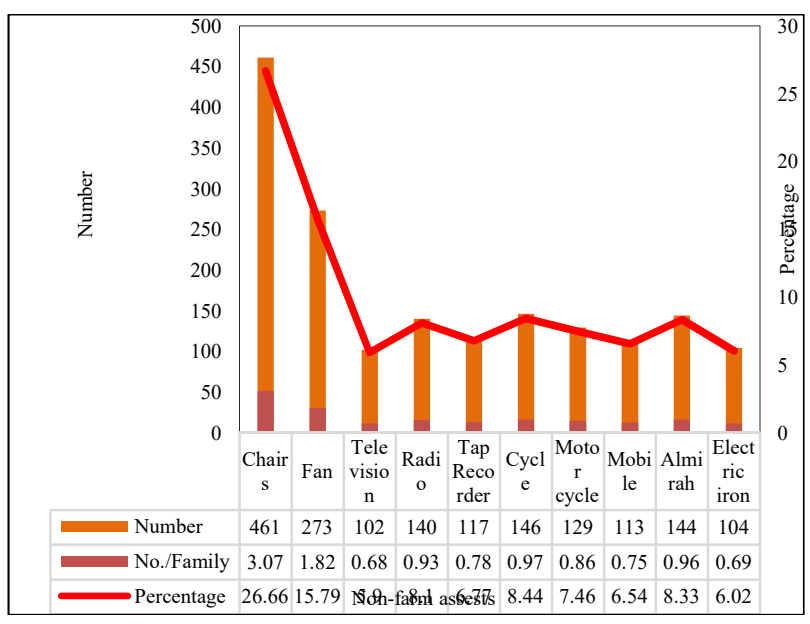

Figure 8: Distribution of non-farm assets of the sampled farmers.

Table 4: Cost of cultivation of wheat crop

\begin{tabular}{|c|c|c|}
\hline $\mathbf{S N}$ & PARTICULARS & COST \\
\hline & . VARIABLE COST & \\
\hline 1 & $\begin{array}{l}\text { Preparation of the Field : Ploughing and Bund Making, 6tr hr } \\
\text { a, Rs. } 500 \text { per hr and } 3 \text { labour } @ \text { Rs. } 150 \text { per day }\end{array}$ & 3450.00 \\
\hline 2 & Manure and fertilizer & \\
\hline & (a)F.Y.M. - 5 Cartload@ Rs.350 per cartload & 1750.00 \\
\hline & $\begin{array}{l}\text { (b)1 pair of bullock@Rs.300 per day and } 5 \text { labour@ Rs. } \\
150 \text { per day. }\end{array}$ & 1050.00 \\
\hline & $\begin{array}{l}\text { (c) Urea-100kg@ Rs.7.0 per kg } \\
\text { DAP-70kg@ Rs.25 per kg }\end{array}$ & $\begin{array}{l}700.00 \\
1750.00\end{array}$ \\
\hline 3 & Seed and sowing & \\
\hline & (a) Seed-130kg@Rs.1800 per q & 2340.00 \\
\hline & $\begin{array}{l}\text { (b) Sowing - } 2 \text { tr hr @ Rs. } 500 \text { per hr and } 2 \text { labour @ Rs.150 } \\
\text { per day }\end{array}$ & 1300.00 \\
\hline 4 & Irrigation $-(1+4)$ & \\
\hline & (a) Irrigation by canal @ Rs.150 per ha & 150.00 \\
\hline & (b) Guiding irrigation water - 2 labour @ Rs. 150 per labour & 1500.00 \\
\hline 5 & $\begin{array}{l}\text { Interculture Operation - } 1 \\
10 \text { labour per weeding and hoeing @ Rs. } 150 \text { per day }\end{array}$ & 1500.00 \\
\hline 6 & Harvesting:20 Labour@ Rs.150 per day & 3000.00 \\
\hline 7 & $\begin{array}{l}\text { Transporting to threshing floor } \\
\text { tr hr@ Rs. } 500 \text { per hr and } 3 \text { labour @ Rs. } 150 \text { per day }\end{array}$ & 950.00 \\
\hline 8 & $\begin{array}{l}\text { Threshing: Power thresher } 20 \text { HP @ Rs. } 500 \text { per hr for } 4 \text { hr and } 10 \text { labour } \\
\text { @ Rs. } 150 \text { per day }\end{array}$ & 3500.00 \\
\hline 9 & $\begin{array}{l}\text { Carting product to market } \\
3 \text { tr hr@Rs.500 per hr and } 2 \text { labour@ Rs.150 per day }\end{array}$ & 1800.00 \\
\hline & TOTAL (1 TO 9) & $24,740.00$ \\
\hline 10 & Interest on working capital@12\% per annum for 6 month & 1484.00 \\
\hline & GRAND TOTAL (1 TO 10) OF A. & $26,224.00$ \\
\hline & B. FIXED COST & \\
\hline 11 & Depericiation on Farm Building@3\% on Pacca & 350.00 \\
\hline
\end{tabular}




\begin{tabular}{|l|l|l|}
\hline 12 & Rental value of land & 300.00 \\
\hline 13 & Cost of management @ Rs. 250 per month for 6 months & 1500.00 \\
\hline & TOTAL (11 TO 13) & $\mathbf{2 1 5 0 . 0 0}$ \\
\hline 14 & Interest on fixed capital @ 12 \% per annum for 6 months & 129.00 \\
\hline & GRAND TOTAL OF B & $\mathbf{2 2 7 9 . 0 0}$ \\
\hline 15 & Total cost of cultivation (A+B) & $28,503.00$ \\
\hline 16 & Yield- & \\
\hline & Main Product- 22 q /ha@ Rs.1600 per q & $35,200.00$ \\
\hline & By product- 22 q/ha @ Rs. 300 per q & $6,600.00$ \\
\hline 17 & Gross Returns & $41,800.00$ \\
\hline 18 & Net Returns & $13,297.00$ \\
\hline
\end{tabular}

\section{Hydrological Status in Command Area}

There was no difference in ground water and surface water quality in command area. No difference in availability and demand of drinking water was found. Many times, water source are not sufficient for agricultural activities in tail command area. This constraint can be resolved by proper irrigation scheduling and development of water allocation plan to achieve uniformity of water distribution throughout the command area of scheme (Rajput et al., 2018. Similar work had been done by other researchers. Machiwal (2001) and Arya (2005) concluded agriculture is the main occupation of the farmers who were the mostly tribal, their literacy percentage and family assets were very low and therefore, the farmers were not aware of new technologies of farming.

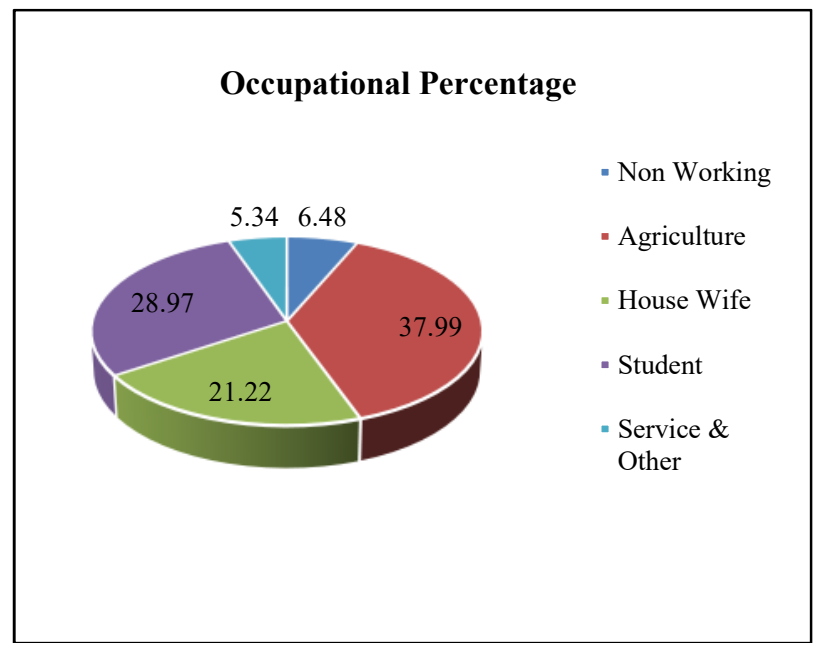

Figure 9: Details of occupational pattern of sample population in command area.

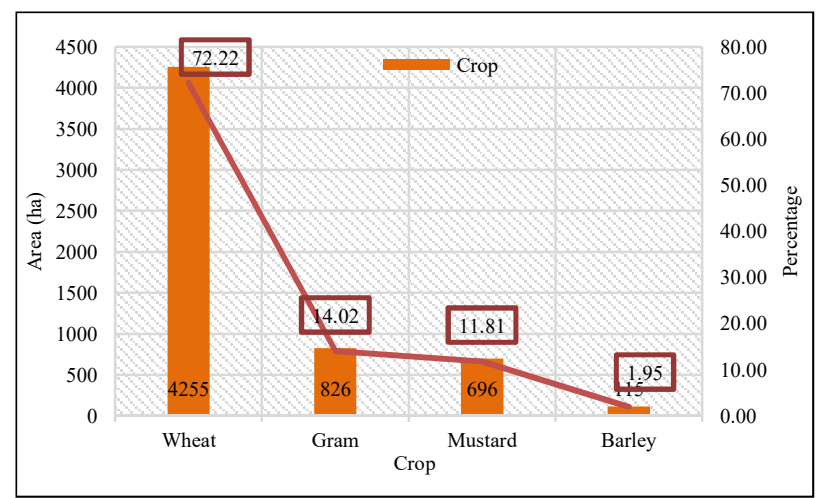

Figure 10: Existing cropping pattern of the Baroda Branch Canal command area for Rabi season in 2013-14

\section{Conclusion}

Farming found to be the primary income source in the study area. Majority of farming communities are tribal; their literacy rate and family assets were relatively low, and as an unaware outcome, the farm owners were of application of modern technologies in agriculture. The analysis of survey stated that the proportion of male and females was 48.16 and 51.84 per cent respectively, the average literacy percentage in the command area was 84.37 most of the farmers belonged to young age group i.e., below 30 years which was followed by middle (i.e., 31 to 49 years) and old (i.e., above 50 years) farmers. In the age group of young, middle and old farmers were $51.33,33.04$ and, 15.63 per cent, respectively. Net benefit per hectare obtained from these crops was Rs. 13,297.00, Rs. 13,023.00, Rs. 14,416, and Rs. 18,303, respectively. Results indicated that area under oil seed crops like mustard may be increased to get more net benefits. 


\section{References}

Akkuzu, E., Ünal, H. B., \& Karataş, B. S. (2007). Determination of water conveyance loss in the Menemen open canal irrigation network. Turkish Journal of Agriculture and Forestry, 31(1), 11-22.

Arya, C. K. 2005. Development of rotational water allocation plan for a command area of left main canal of Som-kagdar irrigation project. M.E. thesis, S.W.E. department, College of Technology and Engineering, Maharana Pratap University of Agriculture and Technology, Udaipur.

Borkar, M. M., Chothe, G. D., \& Lanjewar, A. D. (2000). Characteristics of farmers influencing their knowledge about use of bio-fertilizers. Mah. J. Ext. Edu, 19, 59-63.

Bos, M.G. 1997. Performance indicators for irrigation and drainage. Irrigation and drainage systems, 11: 119-137.

Chahar, B. R., \& Chaudhari, M. (2003). Water logging in Surat Garh branch of IGNP: causes and economic effects. $J$. of Indian Water Resources Society, 23(4), 87-98.

Dahal, A. R. (2013). Impact of irrigation in the command area of Bagmati Irrigation Project. Economic Journal of Development Issues, 1-14.

Hagel, H., Hoffmann, C., Irmão, J. F., \& Doluschitz, R. (2019). Socio-economic aspects of irrigation agriculture as livelihood for rural families in Brazil's semi-arid northeast. Journal of Agriculture and Rural Development in the Tropics and Subtropics (JARTS), 120(2), 157-169.

Jain, P. K. 2000. Optimal crop area allocation model for a minor in a Chambal command. M.E. thesis, Rajasthan Agricultural University, Bikaner.

Machiwal, D. 2001. Stochastic linear programming model for irrigation planning of right main canal of Jakham irrigation project. M.E. thesis, Rajasthan Agricultural University, Bikaner.
Molden, D., Burton, M., \& Bos, M. G. (2007). Performance assessment, irrigation service delivery and poverty reduction: benefits of improved system management. Irrigation and Drainage: The journal of the International Commission on Irrigation and Drainage, 56(2-3), 307-320.

Rajput, J. (2018). Development of Optimum Irrigation Schedule and Rotational Water Allocation Plan for Bhimsagar Canal Command System. International Journal of Agriculture Sciences, ISSN, 0975-3710.

Rajput, J., Kothari, M., \& Bhakar, S.R. (2017a). Performance Evaluation of Water Delivery System for Command Area of Left Main Canal of Bhimsagar Irrigation Project, Rajasthan. Journal of Agricultural Engineering, 54 (3), 5766.

Rajput, J., Kothari, M., Bhakar, S. R., \& Choudhary, R. (2017). Performance Assessment of Bhimsagar Irrigation Project using Technical and Maintenance Performance Indicators.International Journal of Agriculture Innovations and Research, 6(2), 231-235.

Singh, A. K., Rajput, J., Rai, A., Gangwar, A., Shahi, B., Sharma, R. B., \& Rai, V. K. (2020). Socio-economic upliftment of farmers through model irrigated village approach in East Champaran (Bihar), India: A case study. Journal of Applied and Natural Science, 12(4), 556559.

Singh, A., Rajput, G. S., \& Bajpai, A. K., Singh, R. B. 2012. Performance evaluation of a minor irrigation project. IWRA (India) Journal, 1(1), 21-26.

Varhade, R., Raje, S., \& Chafle, P. 2013. Realistic study of rehabilitation and resettlement of project affected persons (PAP's) of Gosikhud project in Maharashtra state. International Journal of Emerging Technology and Advanced Engineering, 3(9), 506-512. 